\title{
Instructional materials development through 4D model"
}

\author{
Ade Gorbi Irawan *', Ni nyoman Padmadewi*2, and Luh Putu Artini ${ }^{* 3}$. \\ Postgraduate program English Education Department, Universitas Pendidikan Ganesha.
}

\begin{abstract}
This research aimed at developing Instructional materials for the second semester students in economy faculty of Panji Sakti University. This research was a Research and Development (R \& D) study. The type of the research was 4D model The steps of this study were: (1)Define,(2) Design, (3)Develop, and (3)Disseminate. In the "Define" step, There were two questionnaires employed in the research: (1) needs analysis questionnaire (2) expert judgment questionnaire. The needs analysis questionnaire was distributed to the students to identify the target needs and the learning needs of the students. The expert judgment questionnaire was used to evaluate the material. The data from the needs analysis questionnaire were analyzed using frequency and percentage and the results were then used as the basis to design and develop the materials, while the data from the expert judgment questionnaire were analyzed using descriptive statistics. Based on the findings from the materials evaluation, the content, the language, the presentation, and the layout of the materials are appropriate. The mean score of all aspects of the developed materials was 4.18. This indicates that the developed material is categorized as excellence material.
\end{abstract}

Keywords: Research and Development , 4D model

\section{Introduction}

English stands as a foreign language. Indonesia has also decided English as a formal subject, that has been taught as a formal subject from primary school to university. In the University, English course that introduced as the general English course and English for Specific purpose. In the English teaching and learning process in the university, the lecturer has to prepare many things such as the material, classroom management, and many other aspects.

Materials take an important part in teaching and learning process [2]. Good and appropriate materials will give positive influence to the students' learning process. From that reason, the researcher conclude that, developing appropriate English learning materials is necessary. It can help the students to learn English more easily. It is because they are learning useful materials that are related to their future job. Nowadays, some universities give opportunity to their students by having special policies, one of those policy was tailored program in which a group of students be able to request the convenient schedule, because they mainly work during the day and continue the study after their finish their work. This situation made the material must mastered in the limited time. The lecturer has to design the learning media which give the learner possibility to study independently. The lecturer does not only have to design the media but also has to find the way to improve the learner motivation, make the learner more active and improve the learner ability.

In the process of developing the appropriate intructional materials, the researcher has to determine the material needed to be developed by using the needs analysis[3][4], there were some steps in developing the instructional materials such as: determining the materials needed, determining the method and evaluate the developed materials to find it's quality . In this study, the main purposes of this research were:

1) To investigatee the materials needs for General English course II for Second semester student of Economic Faculty in Panji Sakti University.

\section{Adegorbi@gmail.com}


2) To develop Instructional materials for the second semester students of Economic Faculty in University of Panji Sakti Singaraja

3) To describe the quality of the designed materials.

In the process of developing the appropriate the instructional materials, the researcher must understand the basic principles materials developments are clearly proposed by [5] the principle explained are as follows:

1. the researcher has to consult the syllabus to identify the theme, sub-theme, the objectives that are prescribed in it and the researcher must consider some sources, such as books, magazines, newspaper, and other authentic materials that related to the topic

2. Materials should be workable for the students and teachable for the lecturer.

3. Material should relevant to the students' level and their real world.

4. Material should suit the students' needs and interests.

5. Material should be feasible to be developed for language skills or language components.

6. Materials should stimulate interaction.

7. Materials should encourage learner to apply their developing language skills to the world beyond the classroom.

Based on the principles of development materials described above, it seems that developing materials should contains 4 language skills namely: listening, speaking, reading and writing which at the same time gives space for language elements, such as structure, vocabulary, pronunciation and spelling in the teaching process in classroom setting. One important thing should be considered in developing materials is the using authentic materials, in which are originally used in real situation and are not designed for use in language teaching, such materials are used in the classroom to expose the learners to language in real use. The using authentic materials are significant because it increase students' motivation for learning, makes the learners be exposed to the real language. The main advantaged of using authentic materials have pointed by [6] are (1) they have positive effect on learners' motivation, (2) they provide authentic cultural information, (3) they provide exposure to real language, (4) they relate to some closely to learners' needs, and (5) they support a more creative approach to teaching.

\section{Method and Instrument}

Here, the researcher using $4 \mathrm{D}$ models [1]. The Four- Door (4D) is a simple instructional design model that helps the researcher to design the product that will help the learner to improve their ability in learning process. $4 \mathrm{D}$ models divide into 4 steps such as: Define, Design, Develop and Disseminate. The participants of the study are 30 second semester students in Economy faculty of Panji Sakti Singaraja.

There were 4 methods of data collection in this study such as observation, interview, questionnaire, and document study. The first question was "what the materials are needed to be developed for the second semester students of economy faculty of Panji Sakti Singaraja? To answer this question, there were some instruments used in this step. Observation sheet, interview, the questionnaire and document study were conducted in this step. To find out The data of needs analysis, the researcher using the observations sheet, questionaire and the interview to find out the material needed by the students.

In this study, the data will be analyzed descriptively. The data from observation, interview, and document study conducted in preliminary observation will be described qualitatively in order to know the problem faced in real situation. While data from the questionnaire will be described quantitatively. In measuring the quality of the developed prototype, the data gathered through some instruments which will be analyzed quantitatively. The validity of the prototype was judged by 2 experts.

\section{RESULT AND DISCUSSION.}

4D models was a simple method in the process of developing a product. The model of research divided into some simple steps namely: "Define", "Design", "Develop" and "Desseminate". The method started by defining the students and material needs. Based the interview and the questionaire result, the Instructional Materials developed based on the student's interest, student's English ability and student needs for supporting the student's future job. The strenght of 4D model was the researcher has to decide the appropriate media and format selection in the step of design. The materials obtained the illustration, and pictures to make the students understand the concept of the material. The design of the materials gave the effect for materials delivery process. [3][7]Materials evaluation was conducted by giving an expert judgment questionnaire to a materials expert in English language teaching. There were five aspects evaluated by the experts such as:

\section{Adegorbi@gmail.com}


The Objectives, Material aspect, methods, learner's aspects, character building, and Instructions of the Material. The result of the questionnaire was explained below: The judge evaluated the material by using instrument in form of evaluation rubric provided by the research.

Table 1: The result of expert judges on the product

\begin{tabular}{|c|c|c|c|c|}
\hline & \multicolumn{2}{|c|}{ Judge I } & \multicolumn{2}{|c|}{ Judge II } \\
\hline $\begin{array}{l}\text { The objectives } \\
\text { of materials }\end{array}$ & 4 & High & 4 & High \\
\hline Materials & 4,15 & Highest & 4.07 & Highest \\
\hline Methods & 4 & High & 4.75 & Highest \\
\hline Learner & 4 & High & 4 & High \\
\hline $\begin{array}{l}\text { Character } \\
\text { Building }\end{array}$ & 4 & High 4 & 5 & Highest \\
\hline Instructions & 4 & High & 4 & High \\
\hline Total Score & \multicolumn{2}{|c|}{4.12} & \multicolumn{2}{|c|}{4.15} \\
\hline
\end{tabular}

The table above presented the result obtained from the expert judges toward the quality of the product. Based on the table, it could be calculated that the mean score from two experts' judge was 4.18, totally there were 24 items examined by the experts' judges. The maximum score could possibly give to each item was 5 while the minimum score was 1 . The materials evaluated by six learning aspect.

Table 3 : The interval score of the category of product quality

\begin{tabular}{|c|c|c|}
\hline Criteria & Interval Score & Category \\
\hline $\overrightarrow{\mathrm{x}} \geq M i+1,5 S d i$ & $\overline{\mathrm{x}} \geq 4.05$ & Excellent Material \\
\hline$\overline{\mathrm{x}} \geq \operatorname{Mi}+0,5 \mathrm{Sdi} \leq \overline{\mathrm{X}}<\mathrm{Mi}+1,5 \mathrm{Sdi}$ & $3.35 \leq \frac{-}{\mathrm{X}}<4.05$ & Good Material \\
\hline$\overline{\mathrm{X}} \geq M i-0,5 S d i \leq \overline{\mathrm{X}}<\mathrm{Mi}+0,5 \mathrm{~S} d i$ & $2.65 \leq \overline{\mathrm{x}}^{<} 3.35$ & Average Material \\
\hline$\overline{\mathrm{x}} \geq M i-0,5 S d i \leq \overline{\mathrm{x}}<\mathrm{Mi}-0,5 \mathrm{~S} d i$ & $1.95 \leq \frac{\mathrm{X}}{\mathrm{X}}<2.65$ & Below Average Material \\
\hline$\overline{\mathrm{X}}<M i-1,5 S d i$ & $\overline{\mathrm{X}}<1.95$ & Poor Material \\
\hline
\end{tabular}

Based on the data above, it could be seen that the mean score of the developed material was 4.18 It indicates that all two judges mostly gave high score to each of item in the instrument. Furthermore, if it was converted into the criteria and category of the product quality, the main score was in the first criteria in which the interval score was $\bar{X} \geq 4.05$. Since the main score obtained from the experts' judgment was 4.18, the developed was categorized as excellent material, or in other words, it was a high quality materials. The last step was "desseminate". Here, the materials formed in the form of module and converted into "Pdf". It format makes the materials be able to opened in the student's smartphone. This strategy gave the students oppurtunity to focus of the process of learning.

\section{Conclusion}

This article has emphasized the significance of instructional materials development in the university. The instructional materials that are appropriate for a particular class need to have an underlying instructional method and

\section{Adegorbi@gmail.com}


technique which suit the students needs[8]. Based on the explanation about the problems faced by the lecturer in teaching English for economy students, it could be concluded that developing instructional materials was very important. it was because the students will use the target language in their future job. The result of developing instructional materials based on the need analysis [3] and the principle of material development [5] will create the appropriate materials which cover the objectives of the English course and student's weaknesses

\section{Acknowledgement}

The result of this research requires a lot of feedback from some supervisor. For their suggestion, supports, guidance, criticism, and motivation during the research. . the researcher could not thank them enough for their dedication, consistency, and commitment.

\section{REFERENCES}

1. Thagarajan, Dorothy S. Semmel. Instructional Development For Training Teachers of $A \quad$ Extional Children A Sourcebook. Bloomington Indiana,Indiana University. (1974)

2. Tomlinson, B. ,Masuhara, H. Developing language course material. RELC , ,1-2(2004).

3. Hutchingson, Tom and alan Waters. Engslish for Specific Purpose: A Learning Centered Approach,Cambridge university press (1987)

4. Richards, Jack C . Curriculum Development in Language Teaching. USA:

a. Cambridge University Press. (2001).

5. A. Kosasang, .The effectiveness of instructional module for teaching

a. culture related in holiday of speakers of English for Mattayom three students, Choochon Tessaban pp. 143-145.( 2003,)

6. Nunan, D. Principles for Designing Language Teaching Materials. $\quad$ Guidelines 10, 1-24 (1988).

7. Tennyson, R, D et.al. Instructional Design; Instructional Perspective, Theory, Research and Model. London: LEA Publishers. (1997).

8. Alan, Maley. Review: Materials evaluation and design for language

a. teaching. ELT Journal, 58(4),394-396. (2004).

9. Sombat Rahmat Using English Instructional Module by B-SLIM Model to

a. Promote English Reading Comprehension of High School Students. International Journal of Information and Education Technology (2016)

10. Pakkan, G. Language Teaching Materials Evaluation and Selection,

a. Adaptation and Development. Istanbul: Sürat ELT (1997). 